O. V. Bereziuk, Cand. Sc. (Eng), Assistant Professor

\title{
SUBSTANTIATION OF THE POSSIBILITY OF THE FLUID DISCHARGE IN THE SEWAGE SYSTEM, OBTAINED BY MEANS OF THE SOLID HOUSEHOLD WASTE DEHYDRATION IN THE PROCESS OF THE LOADING INTO THE DUST-CART
}

\begin{abstract}
In recent years the total area of the solid household waste landfills and sites has considerably increased, this threatens with the pollution of the environment with the harmful substances, including high toxic filtrate. The aim of the research is the substantiation by means of the regressive analysis of the possibility of the discharge in the sewage system the fluid, obtained by means of dehydration of the solid household waste during the loading in the dust-cart, that is actual scientific-engineering problem. The adequate regressive exponential dependence of the percentage ratio of the fluid, discharged from the solid household waste to actual productivity of the waste treatment plants of the sewage system on the population of the city has been obtained. Graphic dependence of the percentage ratio of the fluid, removed from the solid household waste, on actual productivity of the sewage treatment facilities system on the population of the city, that enables to illustrate the given dependence and show the sufficient convergence of the theoretical results with actual results. It is determined that in the cities with the population of at least 200 thousand people, there is a possibility to discharge in the sewage system the fluid, obtained as a result of solid household waste dehydration during the loading in the dust-cart as the percentage ratio of the fluid, removed from the solid household waste to actual productivity of the sewage treatment facilities does not exceed the scientifically grounded value of $0,2 \%$. For the cities with the population of less than 200 thousand people the dependence for the determination of the percentage volume of the possible safe dehydration of the solid household waste with the discharge of the fluid in the sewage system, that is one of the components for the solution of the problem of the creation scientific-engineering fundamentals for the design of high efficient working organs of the mechanisms, intended for the primary processing of solid household waste is suggested.
\end{abstract}

Key words: dust carts, landfill, dehydration, solid household waste, filtrate, sewage network, regression analysis.

\section{Introduction}

Solid household waste (SHW) pose a hazard to the health of people and the environment [1, 2], annually more than 54 mil. $\mathrm{m}^{3}$ of solid waste is generated in Ukraine. Greater part of the domestic solid household waste (SHW) is buried on 6107 landfills and sites, their total area is 7700 hectares, but only a small part of the waste is recycled or disposed at the waste incineration plants, unlike the developed countries, where modern recycling technologies are widely used [3]. During 1999-2014 total area of the landfills and sites in Ukraine increased 3 times. The area of the overloaded landfills increased 2 times and the area of the landfills, that do not correspond to the norms of the ecological safety, including the pollution of the soil by the high toxic filtrate, that can penetrate to the underground waters, polluting them, increased 3.1 times. To reduce the rate of the landfills area increase the technological operation of SHW compaction in the process of the waste loading into the dustcart is performed [6]. High compaction coefficient of SHW makes possible more efficient usage of the landfills area [7]. Transportation of SHW by the dust-carts to the site of the disposal at minimal distance of $30 \mathrm{~km}$ (the dimension of the sanitary zone), in Ukraine is connected with the considerable financial expenses, as the municipal services spend more than 45 thousand tons of fuel per year [8]. Wear of the dust-carts fleet of the municipal enterprises of Ukraine reaches almost 70\% [9], it provides the necessity to manufacture new dust-carts.

\section{Problem set-up}

According to the Decree of the Cabinet of Ministers of Ukraine №265 usage of modern high 
efficient dust-carts is among the priority directions of solid household waste management in Ukraine [10]. That is why, the substantiation of the possibility of discharging in the sewage system the fluid, obtained as a result of the solid household waste dehydration during the loading in the dust-carts is important scientific-engineering problem as one of the components for the solution of the problems, dealing with the creation of scientific-engineering fundamentals of the design of high efficient working organs of the mechanisms, intended for collection and primary processing of the solid municipal waste.

\section{Analysis of the recent studies and publications}

In [11] the hydraulic drive circuit for SHW dehydration and compaction in the dust-cart during the loading and fluid removal into the sewage system is suggested. In $[12,13]$, it was determined that SHW dehydration enables to provide the increase of waste compaction coefficient and reduction of the waste mass to be transported, directly at the place of the collection, perform the preliminary recycling of the waste by means of the dehydration and partial grinding, as well as, as a result of decreasing the volume and mass of the SHW, greatly reduce the increment of the area of the land, allotted for the landfills that will lead to the decrease of the rates of the environmental degradation. In [14], the mathematical model in the form of the logarithmic dependence of the polluting substances concentration in the filtrate of SHW landfills has been improved. In the simplest way the problem of the decontamination of the filtrate in case of its small volume can be solved by means of discharging in the municipal sewage system, if the concentration of the pollution, with the account their dilution does not exceed the established norms [15]. However, in greater part of cases, the filtrate contains high toxic and bio resistive components, that leads to the complication of the sewage treatment process. For instance, in Germany, such common treatment of the filtrate is allowed only if its volume is less than $5 \%$ of the total volume of the waste, supplied to the municipal sewage treatment plants. According to p. 3.113 of the Building code B.2.4-2-2005 [16] the discharge of the filtrate in the municipal sewage system is allowed only in the case if the volume and the composition of the filtrate correspond to the requirements of "Regulations of the waste water collection from the enterprises into municipal and departmental sewage systems of the cities and settlements of Ukraine" by the agreement with the local sanitary epidemiological departments. In [17], by means of longlasting experiments and semi industrial studies the perspectiveness of the filtrates treatment at municipal sewage treatment plants on condition of their dilution by the municipal sewage prior the supply to the purification to the ratio of $1: 500$, i.e., the volume of the filtrate must not exceed $0.2 \%$ from the volume of the waste water, supplied to sewage treatment plants by the sewage networks. In case of such ratio for the mixture of the flows high concentrated filtrates of the landfills do not make negative impact on the activity of the microorganisms of the active sludge and purification effect by the ammonia nitrogen is $92.6 \%$, that almost equals the effect of $95 \%$ purification of the sewage waters without the addition of the filtrate. However, the specific mathematical dependences of the percentage ratio of the removed fluid from SHW to actual productivity of the sewage treatment plants on the population of the city, as a result of the analysis of the known publications the author did not reveal.

\section{Aim and task of the paper}

The aim of the paper is to substantiate by means of the regressive analysis the possibilities of discharging in the sewage system the fluid, obtained by the dehydration of solid household waste during the loading in the dust-cart, that is one of the components for the solution of the problem, aimed at creation of scientific-engineering fundamentals for the design of high efficient working organs of the mechanisms, intended for the collection and primary processing of solid household waste. 


\section{Methods and materials}

For the determination of the regressive dependence of the percentage ratio of the fluid, eliminated from SHW to actual productivity of the sewage treatment plants on the population of the city the following methods are used: regressive analysis of the results of single-factor experiments and other pair dependences, computer modeling.

\section{The results of the research}

Table 1 contains the statistical data, needed for the determination of the percentage ratio of the fluid, removed from SHW to actual productivity of the sewage treatment plants in the cities of Ukraine with different population [18, 19]. On the base of the data, contained in Table 1, it was planned to obtain the pair regressive dependence of the percentage ratio of the fluid, removed from SHW to actual productivity of the sewage treatment plants on the population of the city.

Table 1

Statistical data for the determination of the percentage ratio of the fluid, removed from SHW to actual productivity of the sewage treatment system in the cities of Ukraine with different population [18, 19]

\begin{tabular}{|c|c|c|c|c|c|c|c|c|}
\hline City & Kyiv & Odesa & $\begin{array}{l}\text { Kryvyi } \\
\text { Rih }\end{array}$ & $\begin{array}{l}\text { Vinnytsi } \\
\text { a }\end{array}$ & Rivne & Lytsk & Kramatorsk & Berdychiv \\
\hline Population, ths. people & 2965.5 & 993.1 & 634.8 & 370.8 & 243.9 & 214.0 & 157.2 & 75.44 \\
\hline $\begin{array}{l}\text { Actual productivity of the } \\
\text { sewage treatment plants } \\
\mathrm{m}^{3} / \text { day }[18]\end{array}$ & 725644 & 246301 & 201452 & 64110 & 60000 & 45963 & 21836 & 3918 \\
\hline $\begin{array}{l}\text { Daily-average volume of } \\
\text { SHW }, \mathrm{m}^{3} / \text { day }[19]\end{array}$ & 15500 & 5479 & 4863 & 1954 & 1945 & 1699 & 1509 & 400 \\
\hline $\begin{array}{l}\text { Approximate daily volume of } \\
\text { the fluid, removed from } \\
\text { SHW } \mathrm{m}^{3} \text { /day }\end{array}$ & 817,9 & 289,1 & 256,6 & 103,1 & 102,6 & 89,66 & 79,63 & 21,11 \\
\hline $\begin{array}{l}\text { Percentage of the fluid, } \\
\text { removed from SHW to actual } \\
\text { productivity of the sewage } \\
\text { treatment plants, } \%\end{array}$ & 0,1127 & 0,1174 & 0,1274 & 0,1608 & 0,1711 & 0,1951 & 0,3648 & 0,5388 \\
\hline
\end{tabular}

As the compacting pressure of SHW in the existing constructions of the dust-carts does not exceed $0.1 \mathrm{MPa}$ that is far less than the necessary $10 \ldots 60 \mathrm{MPa}$ [12] for the removal of the humidity, then the obtaining of the statistical data, regarding the real volumes of the humidity, removed from SHW is not possible. That is why, the approximate daily volume of the fluid, removed from SHW by the result of the experimental study [21], which are suggested to realize in practice by means of new construction of the hydraulic drive for the dehydration and compaction of SHW in the dust-cart [11] is determined by the formula

$$
Q_{\text {P.SHW }}=\frac{\left(w_{0}-w_{1}\right) Q_{\text {SHw }} \rho_{0}}{100 \rho}\left[\mathrm{m}^{3} / \text { day }\right]
$$

where $w_{0}$ - initial relative humidity of SHW [20], \%; $w_{1}-$ approximate relative humidity of SHW after dehydration, determined by the dependence, obtained in the paper [21], \%; $Q_{S H W}-$ daily average volume of SHW, $\mathrm{m}^{3} /$ day; $\rho_{0}$ - bulk density of SHW [20], $\mathrm{kg} / \mathrm{m}^{3} ; \rho_{\text {water }}=1000 \mathrm{~kg} / \mathrm{m}^{3}-$ density of the water, $\mathrm{kg} / \mathrm{m}^{3}$.

The percentage of the fluid, removed from SHW to actual productivity of the sewage treatment plants was determined by the formula

$$
\delta Q=\frac{Q_{\text {P.SHW }}}{Q_{\text {P.sew. }}} 100 \%[\%]
$$


where $Q_{\Phi . S H W}$ - actual productivity of the sewage treatment plants, $\mathrm{m}^{3} /$ day.

Regression was carried out on the base of linearized transformations, which enable to reduce the non-linear dependence to linear dependence. Determination of the beta coefficients was carried out, applying the least square method by means of the developed computer program "RegAnaliz", which is protected by the certificate of the state registration of the rights to the copyright objects [22] and described in details in [23].

The results of the regressive analysis are presented in Table 2, where the cell with the maximum value of the correlation factor $\mathrm{R}$ is marked with the grey color.

Thus, by the results of the regressive analysis on the base of the data of Table 1, finally the following regressive dependence was taken as the most adequate

$$
\delta Q=0,1101 e^{129,8 / n} \pm 4,03 \%[\%],
$$

where $n$ - population of the city, ths. of people.

Results of the regressive analysis of the dependence of the percentage ratio of the fluid, removed from SHW to the actual productivity of the sewage treatment plants on the population of the city

\begin{tabular}{|c|c|c|c|c|c|}
\hline № & Type of regression & Correlation factor $\mathrm{R}$ & № & Type of regression & Correlation factor $\mathrm{R}$ \\
\hline 1 & $y=a+b x$ & 0.48365 & 9 & $y=a x^{b}$ & 0.87249 \\
\hline 2 & $y=1 /(a+b x)$ & 0.68724 & 10 & $y=a+b \cdot \lg x$ & 0.79682 \\
\hline 3 & $y=a+b / x$ & 0.94998 & 11 & $y=a+b \cdot \ln x$ & 0.79682 \\
\hline 4 & $y=x /(a+b x)$ & 0.94980 & 12 & $y=a /(b+x)$ & 0.68724 \\
\hline 5 & $y=a b^{x}$ & 0.58520 & 13 & $y=a x /(b+x)$ & 0.92223 \\
\hline 6 & $y=a e^{b x}$ & 0.58520 & 14 & $y=a e^{b / x}$ & 0.95975 \\
\hline 7 & $\mathrm{y}=\mathrm{a} \cdot 10^{\mathrm{bx}}$ & 0.58520 & 15 & $y=a \cdot 10^{b / x}$ & 0.95974 \\
\hline 8 & $\mathrm{y}=1 /\left(\mathrm{a}+\mathrm{be}^{-\mathrm{x}}\right)$ & 0.63042 & 16 & $y=a+b x^{n}$ & 0.34991 \\
\hline
\end{tabular}

As it is seen from Table 2 with the increase of the population of the city the percentage of the fluid, removed from SHW to actual productivity of the sewage treatment plants drops by the exponential dependence.

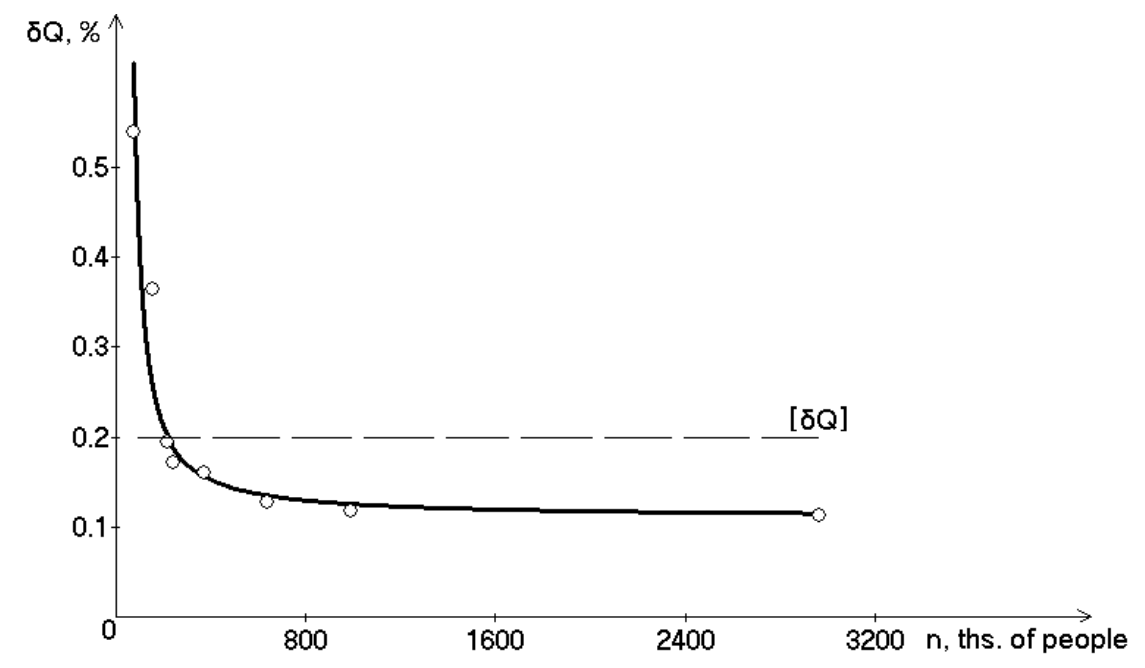

Fig. 1. Dependence of the percentage ratio of the fluid, removed from SHW to actual productivity of the sewage treatment plants on the population of the city: actual $\circ$, theoretical —, admissible - - -

Fig. 1 shows actual and theoretical graphic dependences of the percentage ratio of the fluid, removed from SHW to actual productivity of sewage treatment plants on the population of the city.

The comparison of the actual and theoretical data showed that the theoretical dependence of the Scientific Works of VNTU, 2020, № 2 
percentage ratio of the fluid, removed from SHW to actual productivity of the sewage treatment plants on the population of the city, calculated by means of regression equation (3) does not differ greatly from the data, presented in Table $1[18,19]$, this proves the sufficient accuracy of the obtained dependence.

As it is seen from Fig. 1 in the cities with the population of at least 200 ths. people, there exists the possibility to discharge in the sewage system the fluids, obtained as a result of SHW dehydration during the loading into the dust-cart, as the percentage ratio of the fluid, removed from the SHW to the actual productivity of the sewage treatment plant does not exceed scientifically substantiated in [17] value $[\delta Q]=0,2 \%$. For the cities, where the population is less than 200 ths. people only partial discharge of the fluid, obtained after the dehydration of the SHW during the loading in the dust-cart is possible and the percentage volume of the safe, possible dehydration of SHW for such cities can be determined by the dependence

$$
\Pi_{\text {deh. }}=\frac{[\delta Q]}{\delta Q} 100 \% \pm 4,03 \%=\frac{[\delta Q]}{0,1101 e^{129,8 / n}} 100 \% \pm 4,03 \%=\frac{908,3[\delta Q]}{e^{129,8 / n}} \pm 4,03 \%[\%] .
$$

For instance, for the towns Berdychiv and Kramatorsk the percentage volume of the possible safe dehydration of SHW with the discharge of the fluid in the sewage system, calculated by the dependence (4), is $32,51 \pm 4,03 \%$ and $79,55 \pm 4,03 \%$, accordingly.

\section{Conclusion}

1. It was determined, that with the increase of the population of the city, the percentage of the fluid, removed from the solid household waste to the actual productivity of the sewage treatment plants decreases by the exponential dependence.

2. Graphic dependence of the percentage ratio of the fluid, removed from the solid household waste to actual productivity of the sewage treatment plants on the population of the city is constructed, it enables to illustrate the given dependence and show the sufficient convergence of the theoretical results with actual results.

3. It is established that in the cities with the population of at least 200 ths. people there exists the possibility of discharging in the sewage system the fluid, obtained after the dehydration of the solid household waste during the loading into the dust-cart, as the percentage ratio of the fluid, removed from SHW to actual productivity of the sewage treatment plants does not exceed scientifically substantiated in $[17]$ value $[\delta Q]=0,2 \%$.

4. For the cities with the population of less than 200 ths. people the dependence for the determination of the percentage volume of the possible safe dehydration of SHW with the discharge of the fluid in the sewage system is suggested, it is one of the components for the solution of the problem, aimed at creation of the scientific-engineering fundamentals for the design of high efficient working organs of the machines for the collection and primary processing of solid household waste.

\section{REFERENCES}

1. Qdais Abu H. Kinetics of solid waste biodegradation in laboratory lysimeters / H. Abu Qdais, A. Alsheraideh // Jordan Journal of Civil Engineering. - 2008. - Vol. 2, № 1. - P. 45 - 52.

2. Hamer G. Solid waste treatment and disposal : effects on public health and environmental safety / G. Hamer // Biotechnology advances. - 2003. - Vol. 22, № 1 - 2. - P. 71 - 79. - DOI.org/10.1016/j.biotechadv.2003.08.007

3. Moroz O. V. Economic aspects of solving ecological problems of the solid household waste treatment : monograph / O. V. Moroz, A. O. Sventukh, O. T. Sventukh. - Vinnytsia : Universum-Vinnytsia, 2003. - 110 p. (Ukr).

4. Voronkova T. V. System of the filtrate formation management on SMW landfills / T. V. Voronkova, S. Yu. Chudinov // Solid municipal waste. - 2013. - № 8. - P. 36 - 40. (Rus).

5. Popovych V. V. Ecological danger of the filtrate from the landfills / V. V. Popovych // Material of the $2^{\text {nd }}$ International Scientific-Practical Conference «Ecological safety as the basis of the sustainable development of the society. European Experience and perspectives», November 4-6, 2015. - Lviv, 2015. - P. 165 - 166. (Ukr).

6. Berezyuk O. V. Dynamics of hydraulic drive of hanging sweeping equipment of dust-cart with extended 
functional possibilities / O. V. Berezyuk, V. I. Savulyak // TEHNOMUS - New Technologies and Products in Machine Manufacturing Technologies. - Suceava, Romania, 2015. - № 22. - P. 345 - 351.

7. Berezyuk O. Approximated mathematical model of hydraulic drive of container upturning during loading of solid domestic wastes into a dustcart / O. Berezyuk, V. Savulyak // Technical Sciences. - 2017. - № 20 (3). - P. 259 273.

8. Savuliak V. I. Technical support of the collection, transport and preparation for the treatment of the solid municipal waste : monograph / V. I. Savuliak, O. V. Bereziuk. - Vinnytsia : Universum-Vinnytsia, $2006 .-217$ p. (Ukr).

9. Popovych V. V. Efficiency of the dust-cars operation in the environment "city-landfill" / V.V. Popovych, O. V. Prydatko, M. I. Sychevskyi // Scientific bulletin of National Forest Engineering University (NFEU) of Ukraine. 2017. - V. 27, № 10. - P. 111 - 116. (Ukr).

10. Cabinet of Ministers of Ukraine. Decree № 265 "On the approval of the Program of solid household waste management" [Electronic resource] March 4, 2004. Access mode : http://zakon1.rada.gov.ua/laws/show/265-2004-\%D0\%BF. (Ukr).

11. Bereziuk O. V. Hydraulic drive for dehydration and compaction of solid household waste in the dust-cart. Patient of Ukraine № 109036 IPC (2016.01) B65F 3/00. / O. V. Bereziuk - u201601154 ; appl. 11.02.2016 ; received 10.08.2016, Bull. № 15. (Ukr).

12. Bereziuk O. V. Ways of increasing the efficiency of solid household waste processing in dust-carts / O. V. Bereziuk // Modern technologies, materials and constructions in civil engineering. Scientific-engineering collection - Vinnytsia: Universum - Vinnytsia, 2009. - № 1 (6). - P. 111 - 114. (Ukr).

13. Bereziuk O. V. Drive for dehydration and compaction of solid household waste in the dust-cart / O. V. Bereziuk // Bulletin of machine-building and transport. - 2016. - № 2. - P. 14 - 18. (Ukr).

14. Bereziuk O.V. improvement of the mathematical model of the concentration of the polluting substances in the filtrate of the landfills / O.V. Bereziuk // Bulletin of Vinnytsia Polytechnic Institute.- 2016. - № 4. - P. 28 - 31. (Ukr).

15. Anfimova Yu.V. Filtrate: technologiy of purification / Yu. V. Anfimova, I.S. Glushakova // Solid household waste.. - 2008. - №. 2. - P. $26-31$. (Rus).

16. Building code B.2.4-2-2005. Solid household waste landfills. Main factures of the desing [Electronic
[ resource]. Access mode http://kbu.org.ua/assets/app/documents/dbn2/85.1.\%20\%D0\%94\%D0\%91\%D0\%9D \%20\%D0\%92.2.4-22005.\%20\%20\%D0\%9F\%D0\%BE\%D0\%BB\%D1\%96\%D0\%B3\%D0\%BE\%D0\%BD\%D0\%B8\%20\%D1\%82\%D0\%B 2\%D0\%B5\%D1\%80\%D0\%B4\%D0\%B8\%D1\%85\%20\%D0\%BF\%D0\%BE\%D0\%B1\%D1\%83\%D1\%82\%D0\%BE\% D0\%B2\%D0\%B8\%D1\%85\%20\%D0\%B2\%D1\%96\%D0\%B4\%D1\%85.pdf. (Ukr).

17. Shandrovyck V. T. Increase of the level of the ecological safety, improving the operation of the municipal sewage treatment plants; Dissertation for the degree of candidate of science (Engineering), on speciality 21.06 .01 "Ecological safety" / Shandrovych Vira Tarasivna. - National University "Lvivska Polytechnica", 2015. - 178 p. (Ukr).

18. Ministry of development of communities and territories of Ukraine. National report on the quality of water and state of water supply in Ukraine in 2018. [Electronic resource] Access mode: https://www.minregion.gov.ua/wpcontent/uploads/2019/11/Proekt-Nats.-dop.-za-2018.pdf. (Ukr).

19. Ministry of development of communities and territories of Ukraine. Introduction of the distributed collection of solid household waste on 04.09.2017 [Electronic resource] September 4, 2017 . Access mode: https://www.minregion.gov.ua/wp-content/uploads/2017/10/2017.pdf. (Ukr).

20. Maslennikov A. Yu. Characteristic of solid household waste [Electronic resource] / A. Yu. Maslennikov // Branch portal. Secondary raw materials. - Access mode : http://www.recyclers.ru. (Rus).

21. Bereziuk O. V. Experimental study of the processes of solid household waste dehydration by worm press / O. V. Bereziuk // Bulletin of Vinnytsia Polytechnic Institute. - 2018. - № 5. - P. 18 - $24 . \quad-$ https://doi.org/10.31649/1997-9266-2018-140-5-18-24. (Ukr).

22. Bereziuk O. V. Computer program "Regressive analysis" ("RegAnaliz") / O. V. Bereziuk // Certificate of the state registration of the rights to the copyright object № 49486. - K. : State intellectual property service of Ukraine. Data of the registration : 03.06.2013. (Ukr).

23. Bereziuk O. V. Determination of the waste disposal parameters regression and need in the compaction mechanisms on the base of the computer program "RegAnaliz" / O. V. Bereziuk // Bulletin of Vinnytsia Polytechnic Institute. - 2014. - № 1. - P. 40 - 45. (Ukr).

Editorial office received the paper 14.06.2020.

The paper was reviewed 21.06.2020. 
Bereziuk Oleg - Cand. Sc. (Eng.), Assistant Professor with the Department of Health and Safety, Pedagogy of Safety.

Vinnytsia National Technical University. 